Published in final edited form as:

Biochem Biophys Res Commun. 2015 June 19; 462(1): 33-37. doi:10.1016/j.bbrc.2015.04.098.

\title{
ShRNA-Mediated Gene Silencing of Lipoprotein Lipase Improves Insulin Sensitivity in L6 Skeletal Muscle Cells
}

\author{
Majib Jan and Jheem D. Medh ${ }^{*}$ \\ Department of Chemistry and Biochemistry, California State University Northridge Northridge CA \\ 91330-8262
}

\section{Abstract}

In previous studies, we demonstrated that down-regulation of lipoprotein lipase in L6 muscle cells increased insulin-stimulated glucose uptake. In the current study, we used RNA interference technology to silence the LPL gene in L6 cells and generate a LPL-knock-down (LPL-KD) cell line. ShRNA transfected cells showed a $88 \%$ reduction in the level of LPL expression. The metabolic response to insulin was compared in wild-type (WT) and LPL-KD cells. Insulinstimulated glycogen synthesis and glucose oxidation were respectively, 2.4-fold and 2.6-fold greater in LPL-KD cells compared to WT cells. Oxidation of oleic acid was reduced by $50 \%$ in LPL-KD cells compared to WT cells even in the absence of insulin. The contribution of LPL in regulating fuel metabolism was confirmed by adding back purified LPL to the culture media of LPL-KD cells. The presence of $10 \mu \mathrm{g} / \mathrm{mL}$ LPL resulted in LPL-KD cells reverting back to lower glycogen synthesis and glucose oxidation and increased fatty acid oxidation. Thus, LPL depletion appeared to mimic the action of insulin. These finding suggests an inverse correlation between muscle LPL levels and insulin-stimulated fuel homeostasis.

\section{Keywords}

Lipoprotein lipase; glucose oxidation; glycogen synthesis; fatty acid oxidation; insulin sensitivity; L6 skeletal muscle cells; shRNA

\section{INTRODUCTION}

\begin{abstract}
Lipoprotein lipase (LPL) is a lipolytic enzyme, required for the hydrolysis of triglycerides to glycerol and free fatty acids (FFA) [1,2]. LPL plays a key role in regulating the entry FFA into muscle and adipose cells, both insulin-responsive tissues [2,3]. LPL synthesis is regulated by various metabolic and endocrine stimuli in a tissue-specific manner [3], consistent with the different purposes of LPL activity in different tissues. In adipose tissue, LPL's function is to facilitate the entry of lipoprotein triglycerides into adipocytes for
\end{abstract}

\footnotetext{
(C) 2015 Published by Elsevier Inc.

*Corresponding author: Jheem D. Medh jheem.medh@csun.edu, Telephone: 818-677-7737.

Publisher's Disclaimer: This is a PDF file of an unedited manuscript that has been accepted for publication. As a service to our customers we are providing this early version of the manuscript. The manuscript will undergo copyediting, typesetting, and review of the resulting proof before it is published in its final citable form. Please note that during the production process errors may be discovered which could affect the content, and all legal disclaimers that apply to the journal pertain.
} 
storage. Thus, activity of adipose LPL is increased in conditions of calorie excess. In the muscle, LPL activity releases FFA, which are oxidized for energy; thus, muscle LPL is induced during activity [3

The skeletal muscle accounts for more than $75 \%$ of total insulin-stimulated glucose uptake. Accumulation of muscle fat is associated with reduced glucose utilization and insulin resistance. Since FFA contribute to insulin resistance, regulation of LPL expression and activity can effectively modulate insulin sensitivity. Muscle LPL levels appear to correlate with insulin resistance [4]. Previously, we have demonstrated that siRNA-mediated downregulation of LPL in L6 muscle cells increases insulin-dependent glucose uptake into cells [5]. Down-regulation of muscle LPL may result in unavailability of FFA, which in turn, may force muscle cells to oxidize glucose for energy. Thus, LPL down-regulation appeared to mimic the action of insulin with regards to glucose uptake. Insulin is also known to increase glucose oxidation and glycogen synthesis, whereas it has an anti-lipolytic activity [6]. Thus the present study was to determine the effect of LPL down-regulation on glycogen synthesis, glucose oxidation and fatty acid oxidation in muscle cells. Our results demonstrate that silencing of muscle LPL improves glucose metabolism and insulin sensitivity.

\section{METHODS}

\section{Cell Culture and Differentiation}

Rat L6 skeletal muscle myoblasts were obtained from ATCC and maintained in growth media (DMEM supplemented with10\% FBS (Atlanta Biologicals), 50units $/ \mathrm{mL}$ penicillin, $50 \mu \mathrm{g} / \mathrm{mL}$ streptomycin, $10 \mathrm{mM}$ HEPES, $\mathrm{pH} 7.4$, and $2 \mathrm{mM}$ glutamine) at $37{ }^{\circ} \mathrm{C}$ and $5 \% \mathrm{CO}_{2}$. Every 2-3 days the cells were $75-85 \%$ confluent and passaged at a sub-cultivation ratio of 1:10 using Trypsin-EDTA ( $0.05 \%$ trypsin, $0.53 \mathrm{mM}$ EDTA). For experimentation, myoblasts were sub-cultured into $60 \times 15 \mathrm{~mm}$ petri dishes in the presence of DMEM $+10 \%$ FBS. By day 2, cells were 80-90\% confluent and differentiated to myotubes by reducing the FBS content of the media to $2 \%$ for 2 days and subsequently to $0 \%$ for $2-4$ days till several areas of fused myotubes were evident.

\section{Silencing the LPL Gene}

RNA interference (RNAi) technology was used to generate a stable LPL knock-down (LPLKD) L6 cell line. Lentivirus particles expressing rat LPL-specific short hairpin RNA (shRNA) were integrated into the host genome of L6 cells to silence the host's LPL gene. Cells were seeded into two T- $25 \mathrm{~cm}^{2}$ tissue culture flasks in growth medium at a density of $1 \times 10^{5}$ cells $/ \mathrm{mL}$, and incubated overnight at $37^{\circ} \mathrm{C}$ and $5 \% \mathrm{CO}_{2}$. The next day, when cells were approximately $50 \%$ confluent, spent media was aspirated and replaced with $4 \mathrm{~mL}$ of a mixture of complete growth media supplemented with $5 \mu \mathrm{g} / \mathrm{mL}$ Polybrene. Cells were infected by adding $100 \mu \mathrm{L}$ of LPL shRNA (rat) Lentiviral Particles (Santa Cruz Biotechnology, $0.5 \times 10^{4}$ infectious units $/ \mu \mathrm{L}$ ), chilled on ice for $15 \mathrm{~min}$, and transferred to a $37^{\circ} \mathrm{C}$ incubator for $48 \mathrm{hrs}$. The control flask was handled identically with the omission of Lentivirus. After 48 hours, cells were washed, split from 1 to 3 flasks, and each flask was incubated in complete growth medium for 2 days. Cells stably transfected with the shLPL construct (designated as LPL-KD cells) were selected by treatment with $10 \mu \mathrm{g} / \mathrm{mL}$ 
puromycin dihydrochloride until all cells in the control flask were confirmed dead. The medium was replaced with fresh puromycin-containing medium every 2-3 days, until LPL silencing was confirmed by RT-PCR. For experiments, cells were differentiated to myotubes by culturing in serum-free medium for 4 days. Differentiation was confirmed by the presence of fused multinucleated long myotubes aligned lengthwise.

\section{RNA Isolation and RT-PCR}

RNA was isolated from differentiated myotubes using TRI reagent (Sigma) and Directzol ${ }^{\mathrm{TM}}$ RNA miniprep kit (Zymo Research) according to the manufacturers' protocols. RNA was quantified by spectrophotometry at $260 \mathrm{~nm}$ and $4 \mu \mathrm{g}$ of RNA was used to synthesize cDNA by reverse transcription using Moloney Murine Leukemia Virus Reverse Transcriptase (MMLV RT), dNTPs, and oligodT primers (Promega).

End-point PCR was performed using cDNA and primer pairs shown (Table 1). The PCR amplicons were resolved by $2 \%$ agarose gel and the DNA bands were quantified by ImageJ (NIH) analysis. The cDNA was also subjected to real time quantitative PCR using a Smart cycler (Cepheid Inc), RealMasterMix (5PRIME), and primer pairs shown (Table 1). A melting temperature $\left(\mathrm{T}_{\mathrm{m}}\right)$ of $85{ }^{\circ} \mathrm{C}$ or higher was obtained, confirming primer-specific amplification. $\beta$-actin was used as the house-keeping gene control for both conventional and quantitative PCR. The threshold cycle $\left(\mathrm{C}_{\mathrm{T}}\right)$ values were used to calculate fold change in transcript levels using the $2^{-\Delta \Delta C_{T}}$ method [7] as follows: Fold change $=$ $2-\left(\mathrm{C}_{\mathrm{T}} \text { target }{ }^{-} \mathrm{C}_{\mathrm{T}} \beta \text {-actin }\right)_{\text {siRNA }}-\left(\mathrm{C}_{\mathrm{T}} \text { target }{ }^{-} \mathrm{C}_{\mathrm{T}} \beta \text {-actin }\right)_{\text {control }}$

\section{Metabolic Studies in Cell Culture}

To investigate the effects of LPL down regulation on insulin sensitivity, metabolic assays including glucose oxidation, glycogen synthesis, and fatty-acid oxidation were performed. WT and LPL-KD L6 cells were differentiated as described above. The differentiated myotubes (already serum-starved for differentiation) were simultaneously loaded with radiolabeled substrate (see below) and treated with or without Insulin $(0.004 \mathrm{U} / \mathrm{mL}$, Humulin $\mathrm{R}$ Lilly) for $2 \mathrm{hr}$ or $20 \mathrm{hr}$ prior to a metabolic assay. For 'LPL add-back' experiments, the cell culture medium was supplemented with $10 \mu \mathrm{g} / \mathrm{mL}$ of purified bovine LPL [8] during the incubation with insulin.

Glycogen Synthesis Assay-L6 myotubes in 12-well plates underwent 3 days of serum starvation for differentiation, following which they were incubated for $2 \mathrm{hr}$ or $20 \mathrm{hr}$ ( $20 \mathrm{hr}$ for LPL add-back experiments) in DMEM ( $4.5 \mathrm{mM}$ glucose) without or with insulin (0.4 $\mathrm{U} / \mu \mathrm{L}$ ) in medium containing $0.15 \mu \mathrm{Ci} / \mathrm{mL}$ of $\mathrm{D}-\left[\mathrm{U}-{ }^{14} \mathrm{C}\right]$ glucose. Cells were then quickly washed in icecold PBS and lysed in $0.2 \mathrm{ml}$ of $1 \mathrm{M} \mathrm{KOH}$. Cell lysates were subjected to overnight glycogen precipitation with ethanol. Precipitated glycogen was dissolved in water and transferred to scintillation vials for counting radioactivity. Disintegrations per minute (DPM) were converted to moles of glucose using the specific activity of D-[U-1 $\left.{ }^{14} \mathrm{C}\right]$ glucose (300 Ci/mol) [9].

Glucose Oxidation Assay-Following 3 days of serum starvation, L6 myotubes in $60 \times$ $15 \mathrm{~mm}$ Petri dishes were incubated with DMEM ( $1 \mathrm{mM}$ glucose) medium containing for 
$0.15 \mu \mathrm{Ci} / \mathrm{mL}$ of D-[U- $\left.{ }^{14} \mathrm{C}\right]$ glucose with or without Insulin $(0.4 \mathrm{U} / \mu \mathrm{L})$ for $2 \mathrm{hr}$ or $20 \mathrm{hr}(20 \mathrm{hr}$ for LPL add-back experiments). Each Petri dish was sealed with parafilm after a piece of Whatman paper was attached to the inside of the lid. The Whatman paper was wet with 100 $\mu \mathrm{L}$ of phenylethylamine-methanol (1:1) to trap $\mathrm{CO}_{2}$ produced during the incubation period. After incubation, $200 \mu \mathrm{L}$ of $4 \mathrm{M} \mathrm{H}_{2} \mathrm{SO}_{4}$ was added to the plates, followed by further incubation for $1 \mathrm{~h}$ at $37^{\circ} \mathrm{C}$. Finally, the Whatman paper were removed and transferred to scintillation vials for counting radioactivity [10].

Fatty Acid Oxidation Assay-The procedure for measuring fatty acid oxidation was similar to that for glucose oxidation [11], except that $0.15 \mu \mathrm{Ci} / \mathrm{mL}$ of $\mathrm{D}-\left[1-{ }_{14} \mathrm{C}\right]$ oleic acid was used instead of D-[U- $\left.{ }_{14} \mathrm{C}\right]$ glucose and for all experiments incubations with radiolabel and insulin were done for $20 \mathrm{hr}$.

\section{RESULTS}

In order to study the role of LPL in metabolic functions of insulin, we used shRNA lentivirus to silence the LPL gene in rat L6 skeletal muscle cells. Figure 1 shows the complete absence of LPL mRNA in shRNA transfected L6 cells (designated as LPL-KD cells). Control cells were treated identically, but without the addition of shRNA lentivirus (WT), and showed abundant LPL message. There was no difference in the expression of mRNA for $\beta$-actin, demonstrating that the shRNA specifically targeted only the LPL message. The $\beta$-actin PCR also served as a control for RNA mass and gel loading.

The absence of LPL in LPL-KD cells was also confirmed by real-time quantitative PCR. Table 2 shows the $\mathrm{C}_{\mathrm{T}}$ values obtained for LPL and $\beta$-actin using a Cepheid SmartCycler. While the $C_{T}$ values for $\beta$-actin were relatively similar in WT and LPL-KD cells, the $C_{T}$ value for LPL was significantly higher in LPL-KD cells. Identical results were obtained after repeated experiments. The fold change was calculated using the using the $2^{-\Delta \Delta C} \mathrm{~T}$ method [7] as follows: Fold change $=2^{-\left(\mathrm{C}_{\mathrm{T}} \text { target }\right.}{ }^{-} \mathrm{C}_{\mathrm{T}} \beta$-actin $)$ siRNA $-\left(\mathrm{C}_{\mathrm{T}}\right.$ target ${ }^{-} \mathrm{C}_{\mathrm{T}} \beta$-actin $)$ control This represented a 88\% lower LPL message in shRNA transfected cells (LPL-KD) than in control (WT) cells.

One of the functions of insulin is to increase glucose utilization (glycolysis) and storage (glycogen synthesis) in muscle cells. We compared the insulin sensitivity of WT and LPL$\mathrm{KO}$ cells by measuring the incorporation of ${ }^{14} \mathrm{C}$-glucose into glycogen, and its oxidation to $\mathrm{CO}_{2}$. Figure $2 \mathrm{~A}$ demonstrates the modulation of glycogen synthesis by LPL. For this experiment, cells were grown in complete growth media supplemented with excess (4.5 $\mathrm{mM})$ glucose. In the presence of excess glucose insulin should promote glycogen synthesis. When cells were incubated in the absence of insulin, there is a slight increase in glycogen synthesis in LPL-KO cells compared to WT cells. The presence of insulin marginally increases glycogen synthesis in WT cells but dramatically induces glycogen synthesis in LPL-KO cells to more than twice that in the absence of insulin. Thus, depleting LPL from skeletal muscle cells sensitizes them to insulin.

The negative relationship between LPL protein and insulin sensitivity was confirmed by 'LPL add-back' experiments. Since LPL is a secreted protein, purified LPL protein was 
added exogenously to culture media of muscle cells simultaneously with insulin and the radioisotope. As shown in Figure 2B, incubation of LPL-KO cells with $10 \mu \mathrm{g} / \mathrm{mL}$ purified bovine LPL reduced their ability to synthesize glycogen to a third of the level in the absence of LPL. Stimulation with insulin failed to enhance glycogen synthesis in these cells when LPL was present in the culture medium. As in Figure 2A, insulin stimulated glycogen synthesis in LPLKO cells in the absence of exogenous LPL. Thus, the presence of LPL brings about a resistance to insulin in these skeletal muscle cells.

To measure oxidation of glucose in muscle cells, their supply of glucose was restricted to 1 $\mathrm{mM}$. This limited glycogen synthesis, instead routing the available glucose for harvesting energy via oxidation to $\mathrm{CO}_{2}$. Stimulation with insulin increases glucose oxidation, as confirmed by the results shown in Figure 3A. Insulin induced glucose oxidation in both WT and LPL-KO cells, by $64 \%$ and $84 \%$, respectively. Interestingly, LPL silencing resulted in a 2.3 fold increase in glucose oxidation even in the absence of insulin stimulation. Thus, depletion of LPL mimicked the effect of insulin stimulation in muscle cells. Stimulation of LPL-KO cells with insulin further enhanced glucose oxidation to a level more than 4-fold higher than that in WT unstimulated cells.

The ability of LPL to suppress glucose oxidation was also demonstrated by replenishing LPL in LPL-KO cells by the addition of purified LPL to the culture media. The pattern of glucose oxidation in these cells reverted to that of WT cells. Glucose oxidation was lower in the presence of LPL and higher in the absence of LPL. Thus LPL-depletion appeared to have insulin-mimetic properties with the depletion of LPL and stimulation with insulin having synergistic effects.

Insulin has an anti-lipolytic effect. Thus insulin is expected to reduce fatty acid oxidation [6]. Depletion of LPL from muscle cells has a similar effect. As seen in Figure 4A, LPL-KO cells exhibited only $50 \%$ of the oxidation of oleic acid seen in WT cells expressing LPL. Stimulation with insulin lowered fatty acid oxidation in WT cells, but in unstimulated LPLKO cells, the oxidation of oleic acid was already below the level of insulin-stimulated WT cells, thus insulin did not significantly lower fatty acid oxidation in LPL-KO cells.

As expected, adding back LPL to LPL-KO cells increased fatty acid oxidation both in the presence and absence of insulin. The increase in the absence of insulin was $43 \%$ whereas in the presence of insulin the increase due to LPL addition was only $15 \%$. In this assay also, it was evident that cells depleted of LPL behave as though they have been stimulated with insulin. Thus, silencing the LPL gene 'insulin-sensitizes' the cells.

\section{DISCUSSION}

In previous studies, we have shown that activation of PPAR- $\gamma$ by Ciglitazone treatment of L6 muscle cells resulted in a down-regulation of LPL transcription and translation [5]. Thus, the thiazolidinedione-mediated improvement of muscle insulin sensitivity was shown to be mediated by LPL repression. Concomitantly, when LPL specific siRNA was used to silence LPL expression in rat skeletal muscle cells, there was a co-incident increase in glucose uptake. Thus, in this study, we investigated the wider scope of LPL's correlation to the 
metabolic actions of insulin. A role of LPL in regulating insulin action was demonstrated by two strategies, LPL deficiency and LPL abundance. A rat skeletal muscle cell line was made LPL-deficient by transducing a lentivirus expressing shRNA specific to the LPL gene. Endpoint PCR and realtime quantitative PCR demonstrated a $88 \%$ knock-down of the LPL gene in shRNA transduced (LPL-KO) cells. In another approach, the LPL-KO cells' culture media was replenished with excess purified bovine LPL. Since LPL is a secreted protein, this strategy was akin to LPL overexpression.

Our results clearly establish an inverse relationship between LPL levels and the metabolic actions on insulin. Glycogen synthesis and glucose oxidation in unstimulated LPL-KO cells was equal to or greater than the level in insulin-stimulated wild-type cells. LPL-KO cells stimulated with insulin showed even greater metabolic activity. On the contrary, silencing of the LPL gene reduces the oxidation of oleic acid mimicking the anti-lipolytic activity of insulin. Adding back LPL to the culture medium of LPL-KO cells reverses the metabolic patterns by reducing glycogen synthesis and glucose oxidation, but increasing fatty acid oxidation.

Our results are consistent with prior reports of studies in experimental animals [12-14]. Two studies with muscle-specific over-expression of LPL in transgenic mice showed impaired glucose tolerance and an increase in plasma glucose levels [12,13]. Kim et al also showed a decrease in insulin-stimulated glucose uptake, glycolysis, and glycogen synthesis in the skeletal muscle of these mice [12]. In a reverse study, Eckel's group generated mice with skeletal muscle-specific LPL knockout (SMLPL-/-) [14], and consistent with our data, these mice showed increased insulin sensitivity. While the studies in whole animals are informative, crosstalk between different tissues hinder a clear understanding of the molecular events at the cellular level. Thus, our data obtained in cultured cells are significant, unambiguous evidence of the effect of skeletal muscle LPL on muscle metabolic activity.

There is a direct correlation between the level of free fatty acids (FFA) stored in the muscle and muscle insulin resistance [6]. LPL functions to make FFA available to the muscle cell for energy, and muscle-specific LPL over-expression correlated with accumulation of triglycerides in the skeletal muscle of transgenic mice [12]. Conversely, skeletal musclespecific deletion of LPL resulted in a reduction in muscle triglyceride content [14]. In our study, LPLKO muscle cells may improve their insulin sensitivity due to a repression of cellular FFA uptake. A depletion of available FFA in LPL-KO cells may force the uptake, oxidation and storage of glucose. The scarcity of fatty acids may also explain the decrease in fatty acid oxidation seen in the LPL-KO cells, consistent with insulin's antilipolytic activity.

LPL is not a traditional signaling molecule, however, ours and previous studies establish that modulation of LPL levels in skeletal muscle cells or tissue triggers events that affect the insulin signaling pathway. LPL overexpression in the skeletal muscle of transgenic mice correlated with a significant decrease in insulin-stimulated activation of insulin receptor substrate-1 (IRS-1) associated phosphatidylinositol 3-kinase activity (PI 3 Kinase). PI 3 Kinase is a key intermediate of the insulin signaling pathway, responsible for the metabolic functions of insulin in the muscle $[12,15]$. Mice with muscle-specific deletion of LPL 
showed an increase in insulin-stimulated phosphorylation of Akt, a down-stream effector of PI 3 kinase; however the phosphorylation was independent of PI 3 Kinase activity, suggesting the involvement of another pathway [14]. Thus, in our studies, the down regulation of LPL may trigger signaling events that may lead to metabolic perturbations described here. In future studies, it will be important to map the specific signaling pathway that connects the lack of skeletal muscle LPL to an 'insulinstimulated' metabolic state.

\section{Supplementary Material}

Refer to Web version on PubMed Central for supplementary material.

\section{ACKNOWLEDGEMENTS}

This work was supported by National Institutes of Health Awards R15HL083946 and SC3GM095413.

\section{Abbreviations}

$\begin{array}{ll}\text { FFA } & \text { free fatty acids } \\ \text { LPL } & \text { lipoprotein lipase } \\ \text { LPL-KD } & \text { LPL knock-down } \\ \text { ShRNA } & \text { short hairpin RNA } \\ \text { WT } & \text { wild-type }\end{array}$

\section{REFERENCES}

1. Fielding BA, Frayn KN. Lipoprotein lipase and the disposition of dietary fatty acids. Brit. J. Nutr. 1998; 80:495-502. [PubMed: 10211047]

2. Eckel RH. Lipoprotein lipase, A multifunctional enzyme relevant to common metabolic diseases. New England Journal of Medicine. 1989; 320:1060-1068. [PubMed: 2648155]

3. Kersten S. Physiological regulation of lipoprotein lipase. Biochim Biophy Acta. 2014; 1841:919933.

4. Pulawa LK, Eckel RH. Overexpression of muscle lipoprotein lipase and insulin sensitivity. Curr. Opin. Clin. Nutr., Metab Care. 2002; 5:569-574. [PubMed: 12172482]

5. Lopez V, Saraff K, Medh JD. Down-regulation of lipoprotein lipase increases glucose uptake in L6 muscle cells. Biochem Biophy Res Com. 2009; 389:34-39.

6. Kraegen EW, Cooney GJ. Free fatty acids and skeletal muscle insulin resistance. Curr, Opin.Lipidol. 2008; 19:235-241. [PubMed: 18460913]

7. Livak KJ, Schmittgen TD. Analysis of relative gene expression data using real-time quantitative PCR and the $2^{-\Delta \Delta C}$ method. Methods. 2001; 25:402-408. [PubMed: 11846609]

8. Medh JD, Fry GL, Bowen SL, Ruben S, Wong H, Chappell DA. Lipoprotein lipase-and hepatic triglyceride lipase- promoted very low density lipoprotein degradation proceeds via an apolipoprotein E-dependent mechanism. J Lipid Res. 2000; 41:1858-1871. [PubMed: 11060356]

9. Al-Khalili L, Forsgren M, Kannisto K, Zierath JR, Lonnqvist F, Krook A. Enhanced insulinstimulated glycogen synthesis in response to insulin, metformin or rosiglitazone is associated with increased mRNA expression of GLUT4 and peroxisomal proliferator activator receptor gamma coactivator 1. Diabetologia. 2005; 48:1173-1179. [PubMed: 15864539]

10. Kausch C, Krutzfeldt J, Witke A, Rettig A, Bachmann O, Rett K, Matthaei S, Machicao F, Haring HU, Stumvoll M. Effects of troglitazone on cellular differentiation, insulin signaling, and glucose metabolism in cultured human skeletal muscle cells. Biophys Res Commun. 2001; 280:664-674. 
11. Cha BS, Ciaraldi TP, Park KS, Carter L, Mudaliar SR, Henry RR. Impaired Fatty Acid Metabolism in Type 2 Diabetic Skeletal Muscle is Reversed by PPAR \{gamma\} Agonists. Am J Physiol Endocrinol Metab. 2005; 289:E151-E159. [PubMed: 15727952]

12. Kim JK, Fillmore JJ, Chen Y, Yu C, Moore IK, Pypaert M, Lutz EP, Kako Y, Velz-Carrasco W, Goldbeg IJ, Breslow JL, Shulman GI. Tissue-specific overexpression of lipoprotein lipase causes tissue-specific insulin resistance. Proc Natl Acad Sci U S A. 2001; 98:7522-7577. [PubMed: 11390966]

13. Ferreira LDMC-B, Pulawa LK, Jensen DR, Eckel RH. Overexpressing Human Lipoprotein Lipase in Mouse Skeletal Muscle is associated with Insulin resistance. Diabetes. 2001; 50:1064-1068. [PubMed: 11334409]

14. Wang H, Knaub LA, Jensen DR, Jung DY, et al. Skeletal muscle-specific deletion of lipoprotein lipase enhances insulin signaling in skeletal muscle but causes insulin resistance in ilver and other tissues. Diabetes. 2009; 58:116-124. [PubMed: 18952837]

15. Boucher J, Kleinridders A, Kahn CR. Insulin receptor signaling in normal and insulin-resistant states. Cold Spring Harb. Perspect. Biol. 2014; 6:a009191. (2014). [PubMed: 24384568] 


\section{Highlights}

- The lipoprotein lipase (LPL) gene was silenced in L6 skeletal muscle cells.

- LPL gene silencing resulted in an insulin-mimetic metabolic response.

- LPL-KD cells showed a greater metabolic response to insulin compared to WT cells.

- Replenishing LPL in LPL-KD cells reversed the effect of LPL silencing.

- There is an inverse correlation between insulin sensitivity and LPL levels in L6 cells. 

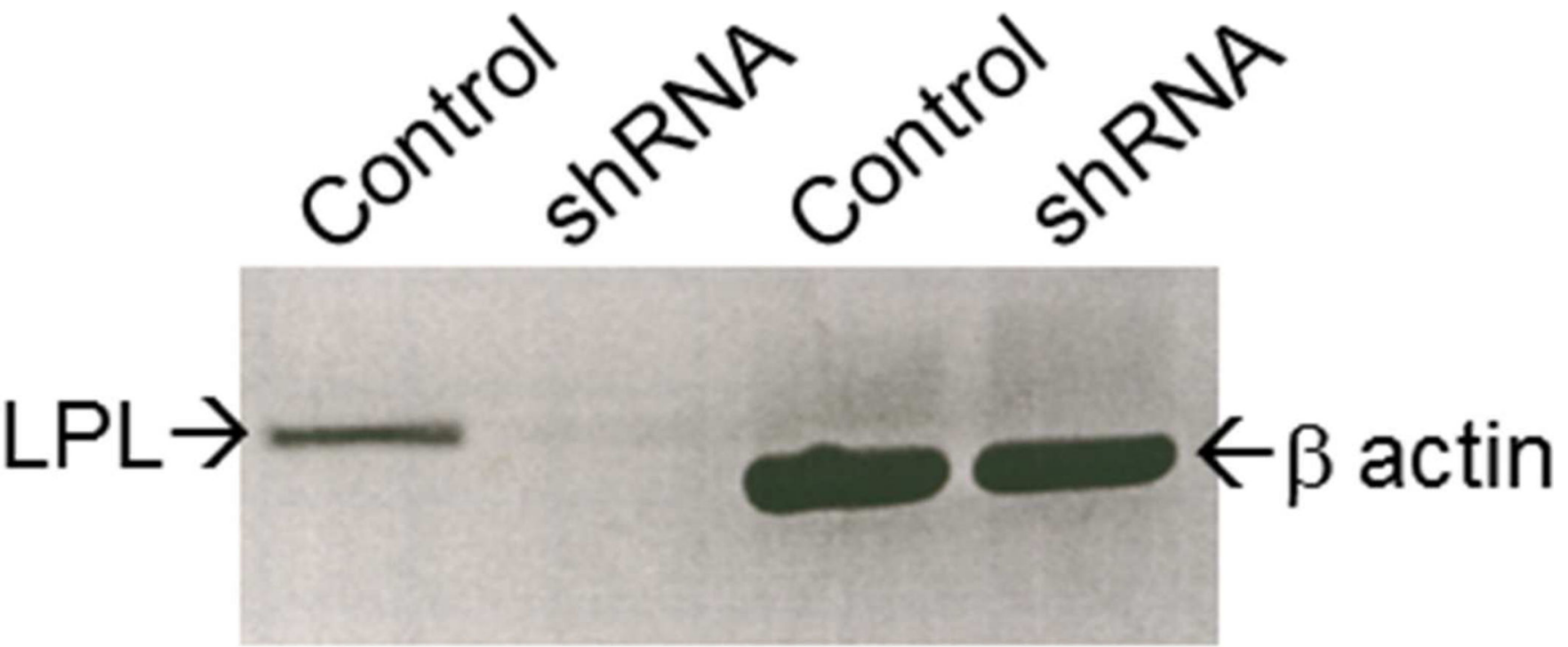

Figure 1. Knock-down of $L P L$ gene expression in L6 muscle cells using shRNA Lentivirus particles

Lentiviral Particles (Santacruz Biotechnology) were used to deliver a plasmid encoding LPL-specific shRNA to L6 myoblasts. Cells with stable expression of shRNA were selected by puromycin treatment and designated as LPL-KD L6 cells. Both WT and LPL-KD myoblasts were differentiated to myotubes as described. End-point RT-PCR analysis shows successful knock-down of LPL mRNA levels by $90 \%$ in shRNA transduced cells (shRNA) compared to wild-type (control) cells. $\beta$-actin was amplified as a control for shRNA specificity, RNA quantification, and gel loading. 


\section{Glycogen synthesis}
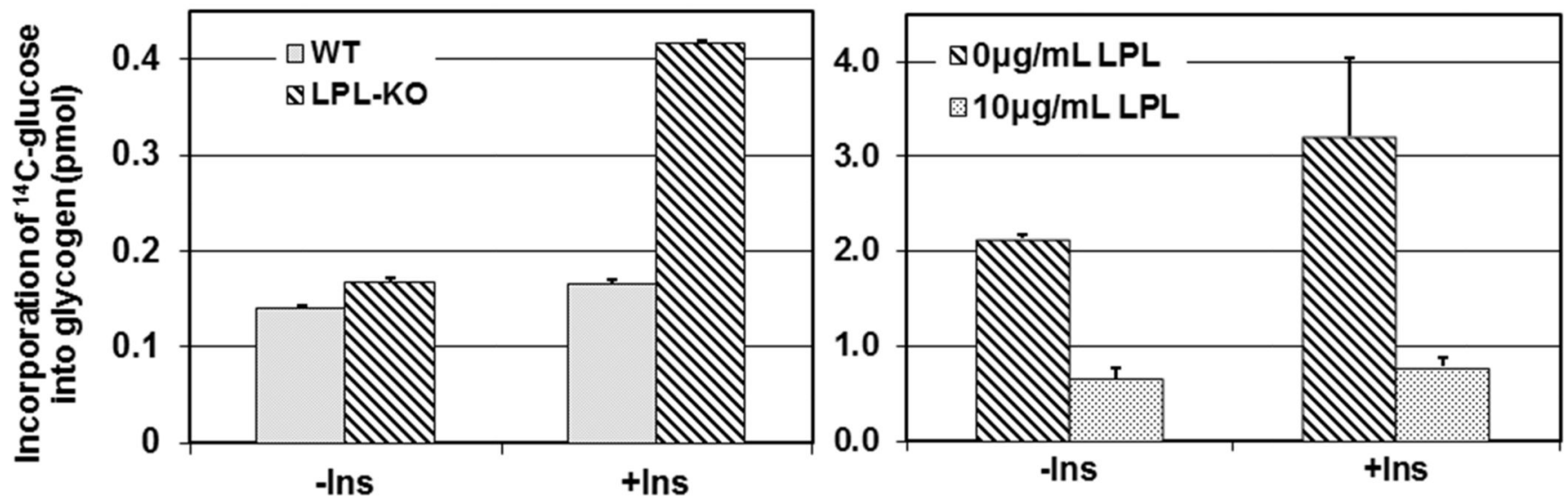

Figure 2. Effect of LPL levels on glycogen synthesis

A. Serum-starved WT and LPL-KD myotubes were treated for $2 \mathrm{hr}$ without or with insulin $(0.4 \mathrm{U} / \mu \mathrm{L})$ in the presence of $0.15 \mu \mathrm{Ci} / \mathrm{mL}$ of $\mathrm{D}_{-}\left[\mathrm{U}_{-}{ }^{14} \mathrm{C}\right]$ glucose. The incorporation of labeled glucose into glycogen was measured as described in 'Methods'. B. Glycogen synthesis was measured as above in LPL-KD cells supplemented without or with $10 \mu \mathrm{g} / \mathrm{mL}$ purified LPL for $20 \mathrm{hr}$ simultaneously during incubation with the radioisotope. Results are averages of 3 replicates \pm standard deviation. 


\section{Glucose Oxidation}
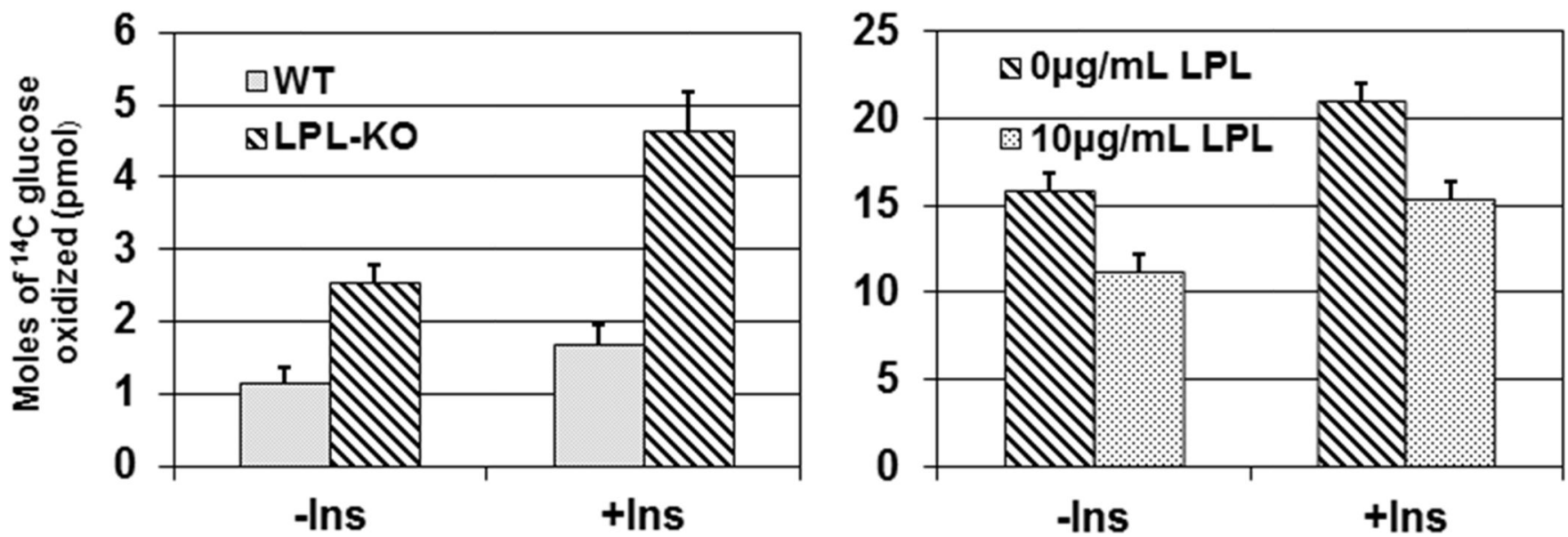

Figure 3. Effect of LPL levels on glucose oxidation

A. Differentiated WT and LPL-KD myotubes in $60 \mathrm{~mm}$ dishes were incubated for $2 \mathrm{hr}$ in DMEM (1 mM glucose) containing $0.15 \mu \mathrm{Ci} / \mathrm{mL}$ of D-[U- $\left.{ }^{14} \mathrm{C}\right]$ glucose and supplemented without or with insulin $(0.4 \mathrm{U} / \mu \mathrm{L})$. Glucose oxidation was measured as described in 'Methods'. B. Glucose oxidation was measured as above in LPL-KD cells supplemented without or with $10 \mu \mathrm{g} / \mathrm{mL}$ purified LPL for $20 \mathrm{hr}$ simultaneously during incubation with the radioisotope. Results are averages of 3 replicates \pm standard deviation. 
Fatty Acid Oxidation
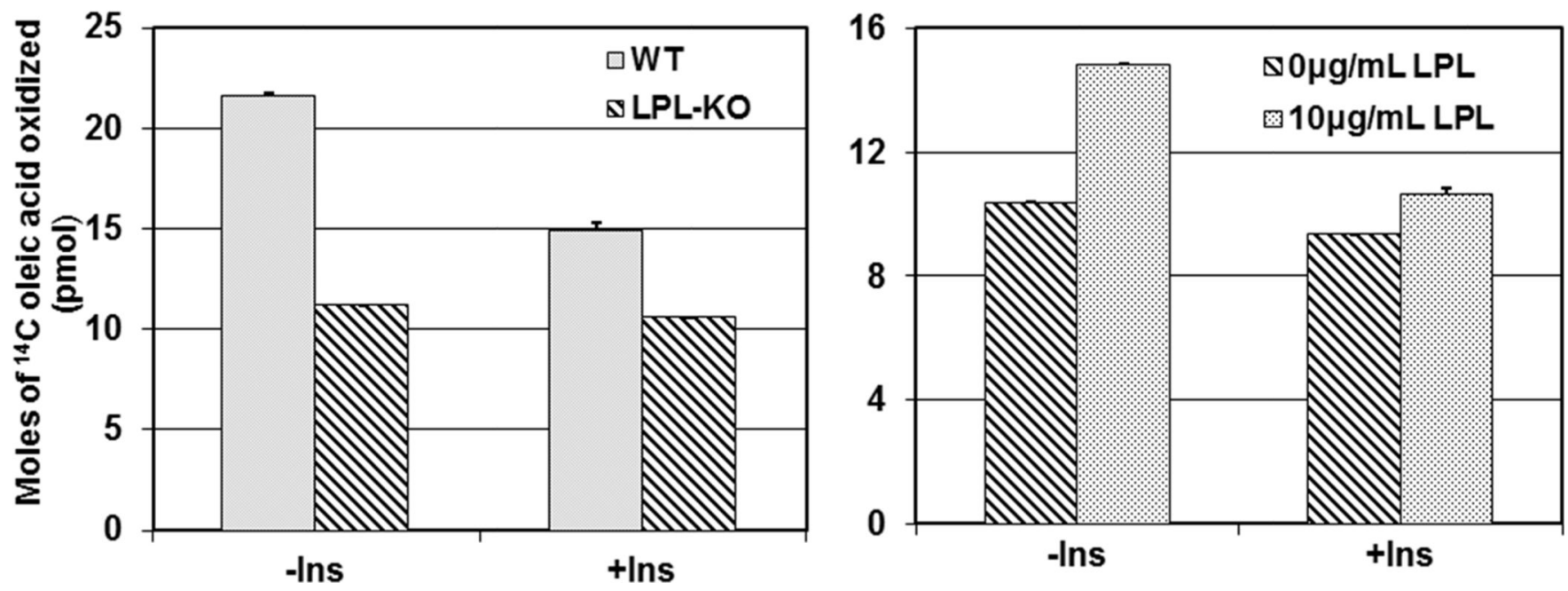

Figure 4. Effect of LPL levels on oleic acid oxidation

A. Oxidation of ${ }^{14} \mathrm{C}$-Oleic acid was measured in LPL-KD and WT L6 myotubes plated on 60x15 mm Petri dishes. Cells were incubated for $20 \mathrm{hr}$ in DMEM (1 mM glucose) containing $0.15 \mathrm{Ci} / \mathrm{mL} \mathrm{D}-\left[1-{ }^{14} \mathrm{C}\right]$ oleic acid with or without insulin $(0.4 \mathrm{U} / \mu \mathrm{L})$. The amount of oxidized oleic acid was determined as described in 'Methods'. B. Oxidation of oleic acid was determined as above in LPL-KD L6 cells in the absence or presence of $10 \mathrm{mg} / \mathrm{mL}$ purified LPL added during the $20 \mathrm{hr}$ incubation with radiolabel. Results are averages of 3 replicates \pm standard deviation. 
Table 1

Primer sequences for end-point and real-time PCR

\begin{tabular}{|c|c|c|}
\hline $\begin{array}{l}\text { Gene \& Amplicon } \\
\text { Size (bp) }\end{array}$ & Primer Type & Primer Sequence \\
\hline \multirow{2}{*}{$\begin{array}{c}\text { LPL } \\
308 \\
\text { (for end-point PCR) }\end{array}$} & Sense & 5'-GGAATGTATGAGAGTTGGGT-3' \\
\hline & Antisense & 5'-GGGCTTCTGCATACTCAAAG-3' \\
\hline \multirow{2}{*}{$\begin{array}{c}\text { LPL } \\
139 \\
\text { (for real-time PCR) }\end{array}$} & Sense & 5'-CCCTAAGGACCCCTGAAGAC-3' \\
\hline & Antisense & 5'-TACATTCCTGTCACCGTCCA-3' \\
\hline \multirow{2}{*}{$\begin{array}{c}\beta \text {-actin } \\
285 \\
\text { (for both end-point } \\
\text { and real-time PCR) }\end{array}$} & Sense & 5'-TCATGAAGTGTGACGTTGACATCCGT-3' \\
\hline & Antisense & 5'-CTTAGAAGCATTTGCGGTGCACGATG-3' \\
\hline
\end{tabular}




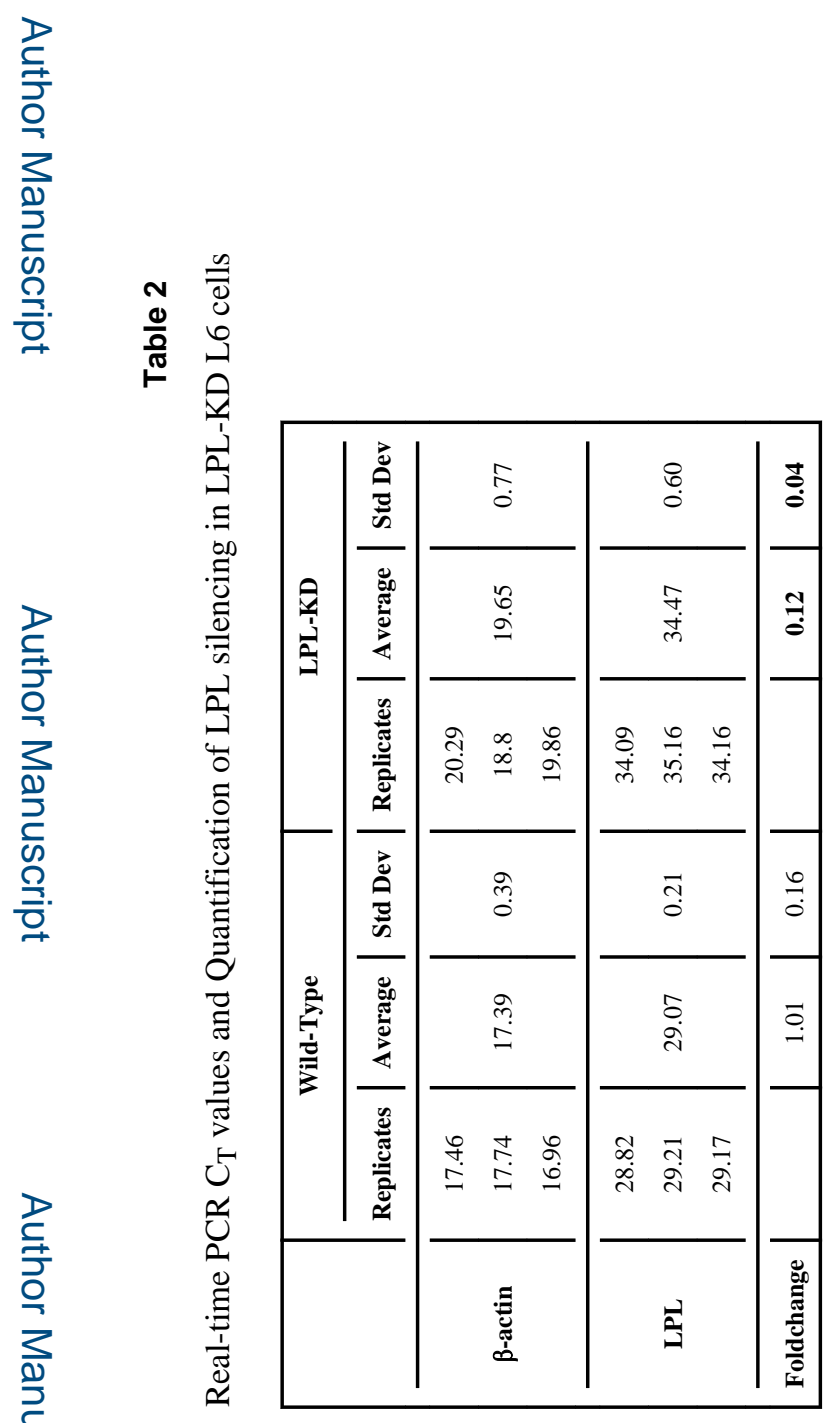

